\title{
Lévinas y el sionismo. Notas sobre geopolítica en el pensamiento de Emmanuel Lévinas
}

\author{
Lévinas and Zionism. Notes on «geopolitics» \\ in Emmanuel Lévinas' thougth
}

RODRIGO KARMY BOLTON*

\begin{abstract}
Resumen: El presente texto tiene por objetivo iniciar una reflexión en torno a la vertiente sionista que impregna la problemática de la ética en el trabajo de Emmanuel Lévinas. Nuestra tesis es que 1) el pensamiento de Lévinas es inseparable del sionismo que le acompaña, y 2) que la adopción levinasiana del sionismo constituiría el síntoma que exhibe la inversión del trabajo de su "maestro" Martin Heidegger en la que el discípulo elaboraría una nueva "geopolítica" característica de la época post-Segunda Guerra Mundial. Palabras clave: Judío, sionismo, Lévinas.
\end{abstract}

\begin{abstract}
The following essay is an attempt to iniciate a research on the zionism that envolves many problems develop in Emmanuel Lévinas's work. Our thesis is that: 1) Lévinas thought can not be separate from zionism and 2) that the levinasian adoption of zionism may be the symptom that shows it's relationship between his «master» Martin Heidegger, where Lévinas draw a new «geopolitics» for the context of the post-Worl War II.
\end{abstract}

Key Words: Jew, Zionism, Lévinas.

«¿Adónde iremos después de la última frontera?

Mahmud Darwish.

Poner en cuestión las fronteras. Las fronteras de la onto-teo-logía, en su frontera más extrema, allí donde quizás, ésta se consuma en la forma de la guerra y su modalidad contemporánea: el exterminio. El exterminio como la frontera de la onto-teo-logía cuya palabra y testimonio, hoy día, lleva el innombrable nombre de Palestina. Palestina de la ocupación, Palestina de la exclusión, Palestina desplazada y refugiada hacia los bordes de toda representación, Palestina que se asoma, incorruptible, como el rostro de su catástrofe (nakba) y, a su vez, como la catástrofe del rostro. Palestina, hoy dividida por un muro que, si bien hasta hace muy poco había sido impuesto contra un cierto Israel, ahora es construido y perpetrado por otro Israel: el Israel del exterminio europeo y el Israel del genocidio contra los palestinos o, si se quiere, el Israel del rostro y el Israel de la guerra, aquél de la ética y aquél de la política. Y si hay un pensamiento ubicado en el quiasmo entre esos dos lugares ha sido el de

Fecha de recepción: 23/04/2013. Fecha de aceptación definitiva: 28/06/2013.

* Doctor en Filosofía. Universidad de Chile, Centro de Estudios Árabes, facultad de Filosofía y Humanidades. Contacto: rkarmy@gmail.com 
Emmanuel Lévinas. Dos lugares que pugnan en su pensamiento y que, sin embargo, ponen en juego un problema cuya interrogación filosófica ha estado sospechosamente ausente de los trabajos sobre su pensamiento: la cuestión del sionismo. El presente ensayo se propone, precisamente, como el inicio de dicha interrogación.

Ante todo, es sabido que el pensamiento levinasiano se presenta como un pensamiento que no deja de interpelar a la mismidad de la onto-teo-logía a partir de la alteridad radical de lo «infinitamente otro». Como veremos con mayor detención, Lévinas utiliza dos nombres que caracterizan a uno y otro movimiento: la mismidad onto-teo-lógica expresará a lo griego, la alteridad radical, a lo judío. Sin embargo, la diferencia entre ambos lugares no debería conducir apresuradamente a atribuirle a dicho pensamiento una cierta «santidad» que parecía dejarlo exento de la violencia de toda onto-teo-logía. Más bien, será preciso preguntarse por el modo en que funciona estratégicamente el término «judío» en Lévinas. Ello, porque, en nuestra perspectiva, el término «judío» se identifica en Lévinas tanto con el pueblo bíblico como con el Estado de Israel a partir de la fuerza y complejidad que tendría el discurso sionista en su pensamiento. Así, ¿como es que el término «judío» se articula como parte de una estrategia propiamente «sionista» en el pensamiento de Emmanuel Lévinas? ¿Cómo es que aquello impactará en su concepción de Europa y en la visión de los procesos de descolonización donde, precisamente, la «cuestión palestina» constituye un hito enteramente decisivo?

\section{Heidegger o la «Escena Primaria»}

Comenzamos con el siguiente acontecimiento que, en la perspectiva de Lévinas, tendrá un carácter tanto biográfico como filosófico: habiendo sido discípulo de Martin Heidegger y testigo de la pronta adscripción del maestro al nacionalsocialismo, Lévinas interpreta el nazismo y la pronta militancia de Heidegger en el «movimiento» como parte de los peligros frente a los cuales la propia filosofía occidental no parecía estar «suficientemente a resguardo». En efecto, en un lúcido post-scriptum escrito en 1990 a su pequeño texto de 1934 Algunas reflexiones sobre la filosofía del hitlerismo, Lévinas comenta:

«El artículo nace de una convicción: que la fuente de la sangrienta barbarie del nacionalsocialismo no está en ninguna anomalía contingente de la razón humana, ni en un malentendido ideológico accidental. Hay en este artículo la convicción de que esta fuente se vincula a la posibilidad esencial del Mal elemental al que la buena lógica podía conducir y del cual la filosofía occidental no estaba suficientemente a resguardo. Posibilidad que se inscribe en la ontología del ser, cuidadoso del ser (...)»l${ }^{1}$.

Muy cerca de la reflexión de la otrora Escuela de Frankfurt, la perspectiva levinasiana está lejos de considerar la violencia nacionalsocialista como una «anomalía» al progreso indefinido de la razón. Más bien, dicha «anomalía» no sería más que una condición estructural a la propia onto-teo-logía. ¿Por qué? Porque si, para Lévinas, hay algo que caracterizaría a dicha deriva, es el montaje de una filosofía de la mismidad que, como tal, no haría

1 Emmanuel Lévinas, Algunas reflexiones sobre la filosofía del hitlerismo. Buenos Aires, Ed. Fondo de Cultura Económica, 2001, p. 23. 
más que aplastar a la alteridad que le resta. En esta lógica, la pregunta heideggeriana por el «ser» constituiría, según Lévinas, la última versión de dicha onto-teo-logía, toda vez que ella misma anunciaría las condiciones de su fin. Me interesa preguntar lo siguiente: ¿en qué medida el «caso Heidegger» y la consecuente «decepción» de Lévinas, no funcionaría en él como su propio reverso especular? Y, por ende ¿hasta qué punto el intento de alejamiento de Heidegger -su éxodo- no terminará por configurar una repetición, un síntoma que cruzaría toda su obra y que le ligará, de un modo tan decisivo como problemático, a rescatar un cierto destino de Occidente arraigado, ahora, en la tradición «judeo-cristiana»? En otras palabras ¿Funcionaría el «caso Heidegger» como una suerte de «escena primaria» que le forzará a repetir la complejidad de una cierta «militancia» con el sionismo, tal como otrora su maestro lo había hecho con el nacionalsocialismo?

El revés existente entre el anti-semitismo y el sionismo fue algo que no pasó desapercibido para una pensadora como Hannah Arendt, cuando en Los orígenes del totalitarismo escribía: «La única consecuencia directa y pura de los movimientos antisemitas del XIX no fue el nazismo, sino, al contrario, el sionismo, que, al menos en su forma ideológica occidental, constituyó un género de contra-ideología, la «respuesta» al antisemitismo»². Si sus palabras encuentran eco, es porque, según Arendt, que ya en Mayo de 1948 había calificado al sionismo como una «pseudosoberanía de un Estado judío», el sionismo lleva consigo el espectro del nacionalsocialismo, en tanto se presenta como su propio revés especular ${ }^{3}$. En este sentido, ¿no podríamos pensar estas consideraciones que hace Arendt respecto de la relación entre Heidegger y Lévinas como la relación propiamente filosófica de dicho envés? «Filosófica» en el sentido de que sus respectivas adscripciones, al nacionalsocialismo uno y al sionismo el otro, contendrían una complejidad que, si bien, no las identificaría plenamente al discurso de los respectivos movimientos, permitiría la articulación de un específico proyecto civilizatorio de carácter europeo y occidental. Como se sabe, en el «caso heidegger», dicho proyecto se resolvía en la restitución de Alemania como «pueblo metafísico», como veremos, en el caso de Lévinas, ello se traduce en la afirmación de una Europa fundada espiritualmente desde una raíz «judeo-cristiana».

\section{2. «Rostro»}

En la perspectiva de Lévinas, la deriva onto-te-lógica de lo griego no sería otra cosa que el movimiento de lo mismo por sobre lo otro, de la libertad por sobre la responsabilidad, del derecho por sobre el deber y, en último término, del predominio de la política por sobre la ética. En este contexto, Lévinas hace una distinción entre dos términos técnicos que configuran la polaridad disyunta de su reflexión: «ontología» que designa aquella doctrina referida al ser y, por tanto, a la perpetuación de la mismidad; y «metafísica», como el terreno de la alteridad que sería constitutivo del pensamiento judío. Para Lévinas, la «ontología» de cariz griego sólo puede aspirar a la guerra, en cambio la «metafísica» que le sobrevive en su cariz judío se escombra como el campo de la paz. A la inversa de la concepción hobbesiana, según la cual, la guerra (el estado de naturaleza y su «guerra de todos contra todos») está

2 Hannah Arendt, Los orígenes del totalitarismo.

3 Hannah Arendt, Salvar la Patria Judía. En: Arendt, Hannah, Una revisión de la historia judía y otros ensayos. Ed. Paidós, pp. 77-94. 
antes que la paz (la artificialidad del Estado que neutraliza el conflicto), para Lévinas la paz conformaría el fondo de la guerra, toda vez que en ella se resuelve la alteridad radical que no deja de conmocionar a la mismidad.

De esta forma, para Lévinas, lo griego, constituido a partir de la idea de la luz del ser y la mirada del hombre, estaría originariamente atravesado por la alteridad que definiría a lo judío y que se caracterizaría por el predominio no de la luz (que no es sino la forma en que tiene lugar la ontología) sino del sonido (que es la dimensión de lo «infinitamente otro») y la escucha:

«Relacionarse con el ente en cuanto ente -escribe Lévinas- significa, para Heidegger, dejar ser a lo ente, comprenderlo como independiente de la percepción que lo descubre y aísla. Gracias a esta comprensión da precisamente como ente y no sólo como objeto. Por ello, el estar-con-otro -el «miteinandersein»- reposa, para Heidegger, en la relación ontológica.» ${ }^{4}$.

Que el «estar-con-otro» haya sido visto por Heidegger desde el prisma de la onto-teología habría constituido el principio de la fatalidad de su pensamiento. Al inscribir esa alteridad al interior del primado de la ontología, éste habría conducido a su filosofía a una alianza mortal para con el nacionalsocialismo. A la inversa, para Lévinas se trataría de indicar el modo en que ese «estar-con-otro» no desarrollado por la analítica existencial heideggeriana, podría ser pensado como el lugar originario del ser.

En otras palabras, la preocupación levinasiana consistiría en subrayar el que desde un principio el ser estaría atravesado por lo «infinitamente otro»y, consecuentemente con ello, cómo es que la condición de posibilidad de la ontología se encontraría en aquello que Lévinas denomina de un modo absolutamente singular bajo el término de «ética»: "La relación con otro -indica Lévinas- no es, pues, ontología» ${ }^{5}$. Ya resulta paradójico el movimiento levinasiano de designar con un término «griego» (ética, precisamente) algo que, en su perspectiva, remite a lo no-griego. Mas, ¿que estatuto tendría esa «relación con otro» que Heidegger habría subsumido al prisma de la ontología? Para Lévinas, esa relación se desenvuelve en lo que él denomina técnicamente «religión» que se define por ser la relación de toda relación que, como tal, apuntala a una filosofía primera que se ha despedido de la «ontología» para desenvolverse en la forma de una «metafísica», esto es, un pensamiento que apunta hacia lo radicalmente otro.

Con ello, el desplazamiento levinasiano que va desde un pensamiento de la presencia (la ontología) hacia un pensamiento de la alteridad (la metafísica), se proyecta, otra vez a la inversa del contractualismo hobbesiano, como un pensamiento que sitúa a la responsabilidad como un lugar originario respecto de aquél de la libertad. Porque si la libertad presupone la soberanía de un «yo puedo», la dimensión originaria de la responsabilidad dislocaría la mismidad de todo yo reconduciéndolo al oscuro campo de la alteridad: «El rostro se niega a la posesión -escribe Lévinas-a mis poderes $»^{6}$. Así, para Lévinas, antes que libres, seríamos responsables. Más, una responsabilidad infinita que excede a cualquier cálculo que algún nómos de la tierra pudiera trazar. Incalculable e inaprensible, pero sin embargo, una epifanía que abre al hombre

\footnotetext{
4 Emmanuel Lévinas, Entre nosotros, p. 18.

5 Idem., p. 19.

6 Lévinas, TI, p. 211.
} 
a lo otro de sí. Con ello, la alteridad levinasiana está lejos de referirse a una simple «representación del otro», al modo de un «alter ego», puesto que la forma «yo» sea un «yo» o un «otro yo», no hace sino perpetuar a la ontología de la presencia puesta en la forma del sujeto. Más allá de ello, para Lévinas se trata de pensar lo que técnicamente denominará «rostro»:

«Según mi análisis - plantea Lévinas en una entrevista-, el Rostro no es en absoluto una forma plástica como un retrato; la relación con el Rostro es, por una parte, una relación con lo absolutamente débil -lo que está expuesto absolutamente, lo que está desnudo y despojado-, es la relación con lo desnudo y, en consecuencia, con quien está sólo y puede sufrir ese supremo abandono que llamamos muerte; así pues, en el Rostro del otro está siempre la muerte del otro y también, en cierto modo, una incitación al asesinato, la tentación de llegar hasta el final, de despreciar completamente al otro; $y$, por otra parte y al mismo tiempo - esto es lo paradójico-, el Rostro es también el "No Matarás"»".

En este plano, el rostro jamás puede ser confundido con una cara, porque si esta última tiene la forma de una presencia, el rostro, en cambio, no es sino la exposición absoluta al modo de una «pasividad más pasiva que toda pasividad»-dice Lévinas en otro lugar. En virtud de dicha pasividad, el rostro comporta una aporía: por un lado, se exhibe como un fenómeno sustraído de toda fenomenalidad posible, arrojado en su más absoluta indefensión y, por otro, como una indefensión que lleva consigo el precepto abrahámico «no matarás» exhortando así a despojarse de todo poder. Como el propio Lévinas indica, la aporía del rostro se podría formular así: expuesto a la muerte y, a la vez, resistente a ella. Precisamente por ello, el rostro no puede conducir a una ética de la igualdad, tal como lo propone la filosofía moderna, porque si fuera así, su carácter de «infinitamente otro» estaría completamente subsumido en la lógica de lo mismo y se confundiría completamente con una cara.

En esa medida, lo que Lévinas denomina «ética» se determinará en una asimetría originaria a través de la cual algo así como una subjetivación podrá tener lugar. Y sólo esta relación «religiosa» que define a la ética será lo que, según Lévinas, permitiría detener la guerra que caracterizará al movimiento de lo mismo. Sólo porque el rostro es capaz de detener la guerra exponiéndose al poder con un «ino matarás!» es que el pensamiento levinasiano conservará una naturaleza esencialmente escatológica: el mesías irrumpe en el momento en que se exhibe la epifanía del rostro impidiendo el continuum de la guerra. Sólo en la dimensión escatológica -una escatología que, en palabras de Lévinas, después de Auschwitz ya no es posible esperar un happy end que permita una suerte de reconciliación- la política es allí suspendida y abierta a la originaria dimensión de la ética. Una ética que carece de contenido y que se erige más allá de toda ley: una ética que será la ética de la ética. Una ética que no tiene más forma que la de una promesa: lo «infinitamente otro».

\section{3. «Deber excepcional»}

Sin embargo, la apuesta levinasiana por el rostro está lejos de renunciar al universalismo. Más, a diferencia del universalismo onto-teo-lógico, Lévinas propondrá un nuevo

$7 \quad$ Idem.p. 130. 
universalismo a través del cual podrá caracterizar al pueblo judío. En efecto, para Lévinas, el pueblo judío será detentor de un cierto universalismo diferente del universalismo basado en la expansión onto-teo-lógica de lo mismo. Así, el universalismo en cuestión, no se identificaría con la figura del «universal concreto» hegeliano, según la cual, el Espíritu en cuanto sujeto se desplegará en una totalidad internamente diferenciada. Más bien, el universalismo levinasiano subraya la dimensión del rostro como aquella frontera que delimita a lo «infinito» que será propio del rostro respecto de la «totalidad» de la figura del Espíritu. De esta forma, a diferencia de la «verdadera infinitud» hegeliana, el universalismo levinasiano abre la zona del «infinito» que será incapaz de ser asimilada a alguna «totalidad».

Con ello, el universalismo de la libertad propio de la herencia griega que encontraría en Hegel su última expresión, será desplazado por el universalismo de la responsabilidad que testimoniaría la inasimilable huella de la herencia judía. A partir del nuevo estatuto del universalismo, Lévinas podrá caracterizar la universalidad en la que se inscribiría al pueblo judío como «pueblo elegido»:

«La idea fuerte del judaísmo consiste en transfigurar el egocentrismo o el egoísmo individual o nacional en vocación de la conciencia moral. En esa perspectiva se sitúa para el judaísmo el papel propio de Israel, su dignidad de pueblo elegido que ha sido frecuentemente ignorada» ${ }^{8}$. Y Lévinas plantea en otro lugar: «Tenemos la reputación de creernos el pueblo elegido y esta reputación provoca mucho daño a ese universalismo. La idea de un pueblo elegido no debe ser considerada como un orgullo. No es conciencia de derechos excepcionales, sino de deberes excepcionales. Es el atributo de la conciencia moral misma. Conciencia que se sabe en el centro del mundo y para ella el mundo no es homogéneo: en la medida que soy siempre el único que puede responder al llamado, soy irremplazable para asumir responsabilidades» ${ }^{9}$.

La reivindicación de la «idea fuerte» propia del judaísmo resultará decisiva por cuanto será allí donde Lévinas se distanciará de cualquier «egocentrismo» sea individual o nacional. Por esta razón, se tendería a pensar que un «proyecto nacional judío» como el sionismo parece distanciarse del pensamiento de Lévinas, toda vez que éste proyectaría la «idea fuerte del judaísmo» en la forma de la «conciencia moral» que, como tal, no deja de sustraerse a toda política.

A esta luz, Lévinas lee la idea del «pueblo elegido» no en la forma del sionismo «político», esto es, como un pueblo que tuviera «derechos excepcionales», sino como aquél pueblo «ético» que asume la actitud de los «deberes excepcionales». Dicho de otra forma, para Lévinas, un «derecho excepcional» será el juego de la política, el «deber excepcional», en cambio, el de la ética. Así, la interpretación que da Lévinas de la noción de «pueblo elegido» convierte a éste en el pueblo moral por excelencia.

8 Emmanuel Lévinas, Los imprevistos de la Historia, pp. 176-177.

9 Emmanuel Lévinas, Difícil Libertad, p. 199. 
Pero, a partir de la triple equivalencia entre «judaísmo», «Israel» y «pueblo elegido» con la que Lévinas trabaja aquí y que en ningún momento especifica el porqué de dicho uso, a la vez idéntico y diferente, la cuestión más problemática se refiere a la siguiente pregunta: ¿que es lo que en Lévinas autoriza a plantear la dimensión pre-ontológica de lo «infinito» en la forma del «pueblo judío»? ¿Por qué éste pueblo y no otro (o incluso lo «infinitamente otro») sería el detentor de la moral de la humanidad? O, a la inversa: ¿por qué el pueblo judío no podría ser un pueblo como los demás, ni excepcional en el derecho, ni excepcional en el deber?

El problema se profundiza cuando Lévinas reconduce esta distinción al viejo apotegma «cristiano» de «da al César lo que es el César y a Dios lo que es Dios». Con ello, la política será representada por la figura de César, la ética, en cambio, por la inconmensurabilidad de Dios. El pueblo judío será tal sólo en la medida que se sustraiga de la política abriéndose a la responsabilidad que aparece bajo el término de «paz» (y, sin embargo, la palabra latina «paz» utilizada por Lévinas le sirve para intentar designar otra cosa, exactamente su sombra):

«La originalidad del judaísmo consiste en plantear el poder político a un lado del poder de la moral absoluta, sin limitar por ello el poder moral al destino sobrenatural del hombre (contra el cristianismo), y sin subordinar el poder moral al poder político, que sería según Hegel el único concreto. Sin embargo, este poder político conserva una cierta independencia. Es laico» ${ }^{10}$.

Según Lévinas, el término clave para calificar al judaísmo es el de «originalidad». Es éste término el que sitúa al judaísmo por fuera de lo histórico, como una entidad inmutable, como si éste tuviera una esencia que, desde el principio, le sería absolutamente constitutiva. Y, más aún: esa «originalidad» no sería otra cosa que el «plantear el poder político a un lado del poder de la moral». Así, la relación del judaísmo con la política sería la de una contigüidad: uno al lado del otro, no uno al frente al otro.

La contigüidad que define la relación entre el «poder moral» y el «poder político» adquiere en Lévinas, la forma de la «disyunción» según la cual ninguno podrá reducirse al otro. Con ello, el poder moral, propio de la «originalidad del judaísmo» nunca llega a identificarse con el poder político que caracterizaría a todo Estado, incluido -porqué noel Estado de Israel. Esta misma diferencia implicaría, entonces, que el «judaísmo» nunca podría ser representado del todo por el Estado de Israel. Aparentemente hemos arribado a una conclusión que salva a Lévinas de un «sionismo político». Sin embargo, como advierte Judith Butler, en la medida que Lévinas posiciona al «pueblo judío» como detentor último del poder moral ¿no reduce a lo «infinitamente otro» a la mismidad de una entidad cultural como la del «pueblo judío» y de ahí a la justificación «moral» de la existencia del Estado de Israel? ¿Con esta estrategia, no se posiciona Lévinas, en favor de un cierto sionismo, cuando todo ofrecía las condiciones para su conjura? ${ }^{11}$.

10 Emmanuel Lévinas, Los imprevistos de la Historia, op. cit., p. 184.

11 Judith Butler, Dar cuenta de sí mismo, p. 130. 


\section{Dos David}

En efecto, una vez que hemos encontrado la «originalidad del judaísmo» (en su carácter a-histórico, es decir, como si ésta hubiese sido desde siempre así hasta nuestros días) Lévinas especifica en qué consiste la noción del «poder de la moral» bajo el sintagma «gobierno de Dios»:

«El gobierno de Dios consiste, en el judaísmo, en someter a los hombres antes a la ética que a los sacramentos, de suerte que la categoría sociológica de religión no calza con el fenómeno judio. Esta categoría le haría perder lo que tiene de más original y, en cierta medida, lo que tiene de opuesto al mito, al misterio, a lo numinoso, a lo dogmático, a lo irracional. Su aplicación haría desaparecer lo que, paradójicamente, comporta de laico» ${ }^{12}$.

El laicismo será, entonces, para Lévinas, herencia judía. Concebir al judaísmo como «religión» significaría desatender la división de aguas que éste introduce entre el «poder moral» y el «poder político», una división que, en el pensamiento levinasiano, quizás tenga como efecto una doble operación:

1. En primer lugar, justificar la fundación del Estado de Israel como un Estado laico toda vez que el «poder moral» del judaísmo se ubicaría en una relación contigua respecto de su propio poder político. Como si ese poder político tuviera que someterse una y otra vez, al escrutinio del poder moral que le excede y le inspira. Como ha visto Jaques Derrida, el Estado de Israel no es pretendido por Lévinas en cuanto entidad propiamente «política», sino como una entidad que se compromete a no ser lo que, sin embargo, es: una promesa ${ }^{13}$. A ello Derrida le llamaría un sionismo que, a diferencia de aquél de carácter «político», se abriría a una «visión escatológica» y en último término, ética. Así, el sionismo levinasiano sería un sionismo propiamente «escatológico» que apuntaría a comprometer al Estado de Israel (política) a honrar al pueblo judío como modelo moral de la humanidad (ética).

2. En segundo lugar, la operación anterior se vincula estrechamente con el intento de inscribir la herencia judía en el seno de una cierta Europa laica. Con esta segunda operación, Lévinas puede vincular el destino del judaísmo con aquél de una Europa laica que no sólo incluya al judaísmo en su centro, sino que además, salve a Europa de su onto-teo-logía. Así, la inscripción del judaísmo en el destino europeo y a Europa refiriéndola a la verdad del judaísmo se vuelve una misma operación de carácter «espiritual». Dicho de otro modo: la salvación de Europa residiría única y exclusivamente en la inclusión del judaísmo como su «originalidad» y la salvación del judaísmo en su retorno a la escena europea. De esta forma, el porqué la filosofía occidental no estaba «suficientemente a resguardo» se explicaría, pues, por su prescindencia de la «originalidad» propiamente judía.

12 Idem.p. 170.

13 Jaques Derrida, Palabra de Acogida, p. 105. 
A esta luz, cobra sentido la diferencia propuesta por el propio Lévinas, entre el Estado davídico de carácter talmúdico (la ética) que correspondería a la «originalidad del judaísmo» en su carácter a-histórico y el Estado davídico de carácter histórico (la política) que podrá tener múltiples significados, pero ninguno «verdadero» como aquél del carácter talmúdico:

«Ese texto extraño formula un desafío a los historiadores, porque afirma la existencia de dos David, y quizá más profundamente aún, afirma que todos los personajes históricos tienen su doble. Desde hace mucho tiempo atrás, los Israelies, e incluso en especial Ben Gurión, se indignan ante la libertad que toma el Talmud con los personajes bíblicos, transformando el David histórico, ese bello fogoso y sanguinario en rabino peinado con papillotes, limitando sus intereses a cuestiones de pureza e impureza (...) ¿Los doctores del Talmud previeron en el texto que nos ocupa la indignación de Ben Gurión? Piensan, en todo caso, que el David de la historia es sólo el segundo, su propio doble, que la significación cobrada por David, más allá de su época, maneja al David real. El David antiguo no es más que el virrey de este otro David "que yo estableceré para ellos” y que es el verdadero David, el David nuevo, el que no es histórico» ${ }^{14}$.

El pasaje es instructivo respecto del funcionamiento de la estrategia levinasiana: en una crítica explícita a la lectura puramente exotérica del Talmud como aquella propiciada por Ben Gurión (que representa la fórmula de la política), según la cual, se «indignan con la libertad que toma el Talmud», Lévinas pone en juego una interpretación esotérica, según la cual, el David histórico siempre lleva consigo a su doble, el «verdadero David» o el David nuevo» que se erige «más allá de su época». Así, pues, para Lévinas David será un doble: uno visible volcado hacia la dimensión propiamente política, y uno invisible de carácter a-histórico que Lévinas denomina el «David nuevo» y que constituye la fuente en que el David histórico encontrará su verdad. En este sentido se comprende porqué el «judaísmo» no podría nunca agotar su sentido en la simple existencia del Estado de Israel sino mas bien, en la promesa que éste llevaría consigo. Frente a la política, representada por la figura de Ben Gurión, Lévinas destaca su fuente, a saber, la ética propuesta por el Talmud. Con ello, Lévinas garantizará la apuesta por el laicismo como fórmula «política» que se apuntala, sin embargo, en el Talmud como dimensión propiamente «ética».

En este sentido, se podría decir que el «verdadero David» constituirá la conciencia moral del frío aparato estatal del «David histórico». Ello implica situar al «verdadero David», en su dimensión a-histórica, como la inspiración ética del «David histórico», su Fuente última, su Espíritu. La discontinuidad originaria entre ambos niveles -y a Lévinas le interesa preservar dicha discontinuidad- no estará, sin embargo, exenta de relación: la contigüidad entre ambos implicará que el David histórico esté inspirado por el «verdadero David». Sólo de esta forma, el Estado de Israel podrá comprometerse con aquello que, estructuralmente no es: la ética, de la cual es detentor «excepcional» el propio «pueblo judío». Mas, en la medida que Lévinas insiste en la dimensión «a-histórica» del «pueblo judío» haciéndolo, por tanto, detentor de «deberes excepcionales», otorga una forma

14 Emmanuel Lévinas, Difícil, op. cit., p. 320. 
«ontológica» para un sitio preontológico, un signo para la a-significancia de lo otro, una cara («pueblo judío») para el lugar de un rostro (lo «infinitamente otro»). Con ello, la mirada escatológica levinasiana, legitima la existencia del Estado de Israel en cuanto apela a lo «infinito» de la promesa que éste lleva consigo.

\section{5. «Europa judeo-cristiana»}

«La tentativa de resucitar un Estado en Palestina -escribe Lévinas- y de reencontrar las inspiraciones creadoras de alcance universal de otros tiempos, no se concibe fuera de la Biblia» ${ }^{15}$.

Que la referencia levinasiana a un «Estado en Palestina» pase por la palabra «resucitar» indica el punto en que éste «David histórico» encuentra una solución de continuidad con el «verdadero David» toda vez que éste funcionará como la Fuente última del primero, como su verdad más decidida. Con ello, el propio Lévinas escribe nuevamente:

«El sionismo y la creación del Estado de Israel significan para el pensamiento judio un retorno a sí en todos los sentidos del término y el fin de una milenaria alienación» ${ }^{16}$.

La «milenaria alienación» resulta del todo una afirmación del todo extraña, sino paradójica, venida del filósofo que no ha hecho más que enfatizar el fuera de lugar en el que se constituye lo humano. En efecto, la apelación a esta «milenaria alienación» no sólo sitúa al «pueblo judío» como una víctima permanente de la historia, sino que además, presupone su pureza. El retorno a esa pureza, esto es, a ese sitial radicalmente pre-ontológico ocupado por el «pueblo judío», constituiría la exigencia ética del naciente Estado de Israel. Sólo con dicha exigencia, dicho Estado propiamente laico podrá resguardar el patrimonio moral judío que, como hemos visto, no será otra cosa que la Fuente última del patrimonio moral de la humanidad:

«El pueblo del libro se esfuerza por advenir un pueblo de la tierra. Pero la esencia religiosa de Israel y de su pensamiento se disimula mal detrás de ese rechazo de Dios. El Estado de Israel se convirtió en el lugar donde el hombre se sacrifica, se separa de su pasado reciente para privilegiar un pasado antiguo y profético, busca su autenticidad $\gg^{17}$.

Apelando al otrora doblez de David, el Estado de Israel se presentará como la cara de un rostro, es decir, aquella visibilidad óntica denominada «pueblo de la tierra» que traduciría esa verdad «metafísica» llamada «pueblo del libro». Ahora ya sabemos hacia donde va ese sionismo escatológico, a saber, a situarse como el lugar puro en el que la actual deriva del Estado de Israel podrá encontrar su «autenticidad». Esta no se podría encontrar

15 Emmanuel Lévinas, Difícil, op. cit. p. 116.

16 Idem.p. 193.

17 Idem. 
en ningún otro sitio más que en su pasado esencialmente «profético». El ejercicio del tiqqun -la redención que encuentra el presente en la vinculación con su pasado- al que apela Lévinas implica situar al Estado de Israel como políticamente laico y éticamente responsable. Pero sólo en la medida que la laicidad política se debe, en último término, a su conducción ética original. Aquí parece tener lugar todo el misterio del doblez de David: el «pueblo del libro» (la pureza, la autenticidad) tendrá que cristalizarse históricamente (es decir, «políticamente») en la forma del «pueblo de la tierra» que representa el Estado de Israel. No habrá uno sin el otro.

En efecto, y tal como hubo indicado Derrida, la aporía levinasiana reside en esto: la alteridad de lo «infinitamente otro» a la cual apela Lévinas no puede tener lugar si no es a partir de la mismidad onto-teo-lógica y viceversa: sólo en razón de esa alteridad originaria es que se podrá distinguir a la onto-teo-logía en su mismidad. Sin la mismidad griega no podría distinguirse la alteridad judía y, a la inversa, sin alteridad judía la mismidad griega carecerá de todo sentido. Si esta circularidad entre lo otro y lo mismo estructura su pensamiento, la forma en la que Lévinas entiende la relación entre el pueblo del libro y su cristalización histórica en el mentado «pueblo de la tierra» cobra todo su sentido: la existencia del Estado de Israel (el pueblo de la tierra o el «David histórico») encuentra su fuente de legitimidad retroactivamente en una «autenticidad» originaria en la que se expresa el «pueblo judío» (identificado ahora al «pueblo del libro» o el «verdadero David»). A esta luz, Lévinas continúa:

«En tanto que, durante siglos, la no participación de la personalidad espiritual de Israel en la historia del mundo se justificaba por su condición de minoría perseguida - itodo el mundo no cuenta con la suerte de tener las manos puras porque es perseguido!-, el Estado de Israel es la primera ocasión de imbricarse en la historia realizando un mundo justo. Es entonces una búsqueda de absoluto y de pureza. Los sacrificios y las obras a los cuales esta realización de la justicia invita a los hombres, vuelven a dar un cuerpo al espíritu que animaba a los profetas y al Talmud» ${ }^{18}$.

Que Lévinas identifique la historia del pueblo judío como de una «minoría perseguida» y que, acto seguido, vincule gratuitamente la característica de ser «perseguidos» con una supuesta «pureza de sus manos», resulta una operación estratégica que intenta posicionar al Estado de Israel en un destino propiamente ético: los perseguidos ahora podrán «imbricarse» en la historia para realizar un «mundo justo». La justicia, entonces, aparece como el horizonte del actual Estado de Israel. Una tarea que se proyecta como una promesa fundada en un retorno permanente a los «profetas y al Talmud». Con ello, el frío cuerpo del Estado adquiere el Espíritu de toda la tradición profética puesto que sólo en dicha tradición el naciente Estado de Israel podrá encontrar su verdad. Más aún, Lévinas establece una analogía entre un pasado profético y un presente estatal, con el Espíritu y el cuerpo, respectivamente: el Espíritu, que corresponde al «pueblo del libro», será constituida por la historia profética y el Talmud; el cuerpo, en cambio, será constituido

18 Idem.pp. 193-194. 
por la naturaleza política del Estado de Israel. Así, el frío cuerpo del Estado adquiere un Espíritu que vendría a suavizar su intrínseca violencia: el cuerpo estatal que se contamina con la historia encuentra su pureza en el Espíritu de la historia profética así como dicho Espíritu logra imbricarse históricamente en función de la realización de la justicia. De esta forma, nos encontramos en la siguiente aporía: si la ética levinasiana no hace sino sustraerse a cualquier forma de presencia ¿cómo podría ésta realizar un «mundo justo» sino es a través de su escena propiamente «política»? ¿No habrá aquí la tenue sospecha de que la pureza de la ética funcionará para purificar la violencia de la política? ¿Y qué significaría aquí «purificar»?

Al respecto, el propio Lévinas distingue tres grandes acontecimientos que, en la perspectiva del pensamiento judío, constituirán los datos de una nueva situación histórica. El primero habría sido la consumación del antisemitismo en la experiencia totalitaria del nacionalsocialismo, el segundo las aspiraciones sionistas que fundan el nuevo Estado de Israel y el tercero, la llegada a un primer plano de «masas subdesarrolladas afro-asiáticas» que, según Lévinas serían «extranjeras respecto de la Historia Santa de donde proviene el mundo judeo-cristiano» ${ }^{19}$. En este contexto se pregunta:

«El crecimiento de las innumerables masas de los pueblos asiáticos y subdesarrollados, ¿no amenaza el reencuentro de esta autenticidad? Vemos sumarse a la escena del mundo pueblos y civilizaciones que no se refieren ya a nuestra Historia Santa -para quienes Abraham, Isaac y Jacob no significan más nada-»20.

La caracterización de esos «pueblos africanos» y «asiáticos» como «masas subdesarrolladas» que, por serlo, parecen amenazar el «reencuentro de esta autenticidad» realiza una estrategia en favor de un cierto proyecto civilizacional de corte europeo. Un proyecto que distingue entre un «nosotros» que perteneceríamos al legado de una cierta «Historia Santa» y ellos (las masas subdesarrolladas afro-asiáticas) que, según Lévinas, estarían absolutamente excluidos de dicha historia, cuestión que determinará la articulación de Europa como una comunidad espiritual a la que pertenecen algunos y otros no. Y entre los que pertenecen a esta nueva Europa estará, por cierto, el Estado de Israel, toda vez que el propio Lévinas no sólo ha defendido a dicho Estado al alero de un proyecto laico (exactamente como el de Francia), sino como aquél que lleva en su seno la autenticidad necesaria del «pueblo judío» cuyo despliegue tendrá la forma de la realización de un «mundo justo». Así, el sionismo escatológico levinasiano redundará en una verdadera geopolítica de corte espiritual que rearticula el proyecto civilizacional europeo después del fin de la Segunda Guerra Mundial a partir de la pertenencia a una supuesta «Historia Santa».

Y será precisamente aquí donde Lévinas se confiesa estratégicamente: esa «Historia Santa» fundaría una verdadera comunidad espiritual de carácter «judeo-cristiano» respecto de la cual, las «masas subdesarrolladas» de África y Asia, no sólo no pertenecerían, sino que además, amenazan a Europa y al naciente Estado de Israel con la posibilidad de no encontrar

19 Idem., p. 188.

20 Idem., p. 194. 
la «autenticidad» legada por el pueblo del libro. Lévinas continúa sus comentarios pero ahora refiriéndose al marxismo como parte del mentado legado «judeo-cristiano»:

"Quizás estemos ligados todavía a este mundo enorme que surge ante nosotros mediante una suerte de lazo inmediato y único provisto por el marxismo, en el que todavía reconocemos una parte de la herencia judeo-cristiana. ¿Pero esas infiltraciones marxistas no van a perderse también ellas en todo el espesor de esas civilizaciones extranjeras -Lévinas se refiere a las de aquellas «masas afro-asiáticas»- $y$ de esos pasados impenetrables? $»^{21}$.

Contrariamente a cualquier conciencia contra-revolucionaria que tendería a ver en el marxismo la debacle de la civilización occidental, Lévinas advierte en él la posibilidad de conservar la cultura «judeo-cristiana». Y se pregunta-de modo retórico por cierto, ya que antes ha dicho que ni los africanos ni los asiáticos pertenecerían a la mentada «Historia Santa»- si acaso este marxismo no sufrirá su propia «perdición» en el espesor de las «civilizaciones extranjeras» que, por serlo, no pertenecen al mentado legado judeo-cristiano. En este sentido, la estrategia levinasiana funciona a la perfección. Y, sin embargo, quizás con ello no hace más que reproducir de manera invertida al caso Heidegger: al igual que en Heidegger, en Lévinas asistimos a una política del Geist, pero si para el primero se trataba de proyectar al pueblo alemán como un pueblo propiamente metafísico capaz de salvar a Europa del nihilismo, para Lévinas, se tratará de atender al Estado de Israel en virtud de la Fuente moral que le alimenta, en la que el pasado del «pueblo judío» conservaría para sí su excepcionalidad ética proyectándola históricamente en la forma del Estado de Israel. Estado que se inscribiría en el marco de una Europa que, gracias a su núcleo absolutamente «judío» y de su pertenencia a la comunidad espiritual de la «Historia Santa», podrá, en efecto, ser salvada. Con ello, al igual que Heidegger, el proyecto levinasiano se inscribe como una geopolítica que redundará en una nueva forma de euro-centrismo ahora moral y cuya matriz no se encontrará en los pre-socráticos de Heidegger, sino en el «pueblo del libro» como su lugar más originario.

Así, la apuesta levinasiana deviene la forma propiamente «política» (El «David histórico») de una restauración laica en el seno de una Europa que ha sobrevivido a su propia catástrofe y cuya proyección dependerá de la fidelidad a la «pureza» de esa tradición judeo-cristiana. En efecto, hemos visto que Lévinas no descarta la dimensión política, sino que más bien, intenta reinscribirla en el horizonte de la ética. Reinscripción cuyo punto de cruce lo constituye el Estado de Israel, es decir, la cristalización del «verdadero David» en la forma del «David histórico» cuya obra estará dada por la exigencia ética del primero y que le impulsará a construir el mentado «mundo justo». De esta forma, ¿no será la apelación a la pureza, autenticidad de ese «pueblo judío» lo que permitirá a Lévinas construir toda su geopolítica, el nuevo reino que vendría a sustituir, gracias al progresivo triunfo del liberalismo a nivel planetario, a la política que no habría hecho otra cosa que conducir a la humanidad a su ruina? ¿Significa esto que la conclusión levinasiana de la Segunda Guerra Mundial es que, finalmente, la política requiere de la ética como contra-

21 Emmanuel Lévinas, Difícil Libertad, op. cit., p. 195. 
peso y que, en este equilibrio de fuerzas, la única forma que Europa no vuelva a sucumbir a la catástrofe, sea situando al Estado de Israel como su más prístina conciencia moral?

\section{Sionismo Escatológico}

En un pequeño pero interesante texto titulado Lo político en Lévinas (hacia una filosofía política crítica), Enrique Dussel plantea lo siguiente: «La posición de Lévinas era una posición cuasi sionista (ciertamente anti-fundamentalista, antidogmática, por abrirse a una posición política más liberal, en cuanto a las instituciones concretas políticas del Estado de Israel desde 1948). Por ello, para Lévinas, tanto su situación en el Estado francés al que tanto admiraba, como la creación del Estado de Israel, aportaban nuevos elementos para una solución del antiguo conflicto judio. La comunidad profética se transformaría por la creación del Estado israelita, para Lévinas, en una comunidad davídica que podía construir la paz (...) » ${ }^{22}$ ¿Que puede significar el término «cuasi», sino un acercamiento al sionismo de un modo liberal y, por tanto, anudado a un determinado proyecto europeo «occidental» proyectado desde finales de la Segunda Guerra Mundial? Curiosa escena: en los últimos años, después de un arduo trabajo filosófico en los que ha destacado aquellos de Jean-Luc Nancy y Phillipe Lacoue-Labarthe, se ha mostrado la dimensión propiamente «nacional-esteticista» 23 de la apuesta de Heidegger, en relación a la deriva ideológica del Tercer Reich, y sin embargo a Lévinas, el pensador del rostro, de lo «infinitamente otro», la filosofía contemporánea, parece haber dejado en la sombra cualquier trabajo crítico en relación a la adopción del sionismo. Quizás, lo que aquí se juega, es que poner en evidencia el «sionismo escatológico» levinasiano significa no sólo poner en discusión su perspectiva «colonialista» sino también, problematizar la articulación liberal de la Europa de finales de la Segunda Guerra Mundial. En este plano, el diagnóstico dusseliano sobre lo político en Lévinas, me parece complicado a la hora de tratarlo simplemente como «anti-fundamentalista» o «anti-dogmático» cuando, según hemos visto, su tratamiento de las «masas afro-asiáticas» en base a la «pureza» inmanente a la «Historia Santa» expresa exactamente lo contrario. Y precisamente por las razones que esgrime Dussel, respecto de la órbita entre el Estado francés y el Estado de Israel de la que, según Lévinas, depende Europa, me parece que, al identificar en la figura del «pueblo judío» aquello que estaba reservado a la alteridad radical, ésta pierde precisamente su radicalidad, repitiendo así, el gesto de su maestro. Con ello, se revela en qué redunda el mentado rostro de la ética levinasiana, a saber, en un hombre europeo de la cultura «judeo-cristiana».

En su obra Palabra de acogida Jaques Derrida problematiza la relación levinasiana respecto de la política, señalando como es que en Lévinas habría una «prudente» interpretación del sionismo: "“¡Política después!” Bajo este título una interpretación tan prudente del sionismo se esfuerza en distinguir, con o sin razón, entre dos grandes fases $»^{24}$. Inmediatamente Derrida se pregunta cómo es que habría que entender estas dos fases: ¿cómo dos fases cronológicas (una después de otra) o como «dos sionismos» que coexisten de manera inconciliable? Después de afirmar que Lévinas parece privilegiar la diacronía en su análisis,

22 Enrique Dussel, Lo político en Lévinas, p. 11.

23 Phillipe Lacue-Labarthe, Heidegger y el poema.

24 Jaques Derrida, Palabra de acogida, p. 105. 
Derrida distingue entre un sionismo «político» que tendría la forma de un nacionalismo heredero del anti-semitismo europeo decimonónico, respecto del cual, el «ideal profético» sería completamente inadecuado, y un sionismo que «(...) se abriría más a la visión escatológica de la historia santa o bien, y por ello mismo, político más allá de lo político (... $)^{25}$. Este segundo sionismo - plantea Derrida que está «más allá de lo político» implicará leer no el hecho sionista de la fundación del Estado de Israel, sino la promesa de «(...) pensar una paz que no sea puramente política (...)» ${ }^{26} \mathrm{o}$, lo que es igual, el compromiso que se desprende del hecho de la fundación de dicho Estado. Como hemos visto, esa promesa, no es más que el tiqqun que Lévinas interpreta y que le permite conducir al inerte «cuerpo» estatal a la poderosa vida del «Espíritu» moral. El pasado entra en el presente, el «verdadero David» ingresa al «David histórico» imprimiéndole así, la necesaria fuerza espiritual para producir «un mundo justo».

Siguiendo a Derrida, nuestra conclusión es que, exactamente como ocurrió con la adscripción nacionalsocialista de Heidegger, el sionismo levinasiano no sería un sionismo puramente «político» restringido al David histórico representado por Ben Gurión, sino mas bien, a un «sionismo escatológico» cuya traducción política se cristalizará en la forma de un sionismo propiamente «laico» y liberal que será tal, precisamente porque su promesa espiritual excede a su factum corporal. «Sionismo» porque su pensamiento da legitimidad moral a la creación del Estado de Israel y «escatológico» porque sería un sionismo que, como hemos dicho, no se agota y no se reduce al exoterismo de la política estatal, sino que más bien, conservaría consigo el legado del «verdadero David» situándose así, en el faro moral de la nueva Europa que ha emergido desde las ruinas de la Segunda Guerra Mundial. Así, el David histórico sólo podrá proyectarse políticamente si no deja de volver hacia su pasado cuyas tenebrosas «persecuciones» mantuvieron las «manos puras» del «verdadero David» que sería eterno y sin fin. Así, la escatología levinasiana es una escatología abierta que da curso a que la realización de un «mundo justo» se presente como una tarea estructuralmente infinita. Porque, precisamente, será esa «autenticidad» proveída por el «verdadero David» lo que vitalizará e impedirá el descarrío moral no sólo del Estado israelí, sino también del proyecto europeo en general.

La «cuestión palestina» será un quiasmo producido por la «cuestión judía». Como hemos visto, ese quiasmo que, en parte, se denomina «sionismo» no pretende ser dislocado por Lévinas, sino más bien, se propone ser reinscrito en el nuevo proyecto de la Europa liberal, insistiendo en la disyunción estructural entre la ética y la política. Frente a la solución de continuidad con la que el ideologema sionista identifica en el significante «Israel» tanto al «pueblo judío» como al «Estado israelí», Lévinas va a distinguir dos esferas del mismo. Una esfera ética, que constituye la Fuente propiamente espiritual de la esfera la política, que la intenta llevar a cumplimiento. Las fronteras están hoy acabadas. Y sin embargo, siguen rodando. Con ello, frente al katechón de la teología política israelí, Lévinas sitúa un eschatón que le impone sus límites propiamente «liberales». Por ello, éste último va más allá del primero, le excede, pero nunca lo sustituye, porque ambos se co-pertenecen en su propia disyunción.

25 Idem.

26 Idem. 
$\mathrm{Al}$ principio de este escrito, decíamos que éste era un escrito fronterizo. De las fronteras de la onto-teo-logía y de las fronteras que se inscriben en la ocupación de Palestina. Las fronteras de Palestina y Palestina como frontera. Abandonada por los Estados nacionales y los humanitarismos trasnacionales, Palestina se ha transformado en la frontera de todas las fronteras, en la zona porosa en que los documentos se diluyen, las hablas se mezclan y las confesiones confiesan una guerra abierta. Palestina, como frontera, constituye el punto cero de nuestro presente. Lo inasimilable, lo ominoso que destempla a todo templo, el temblor que acompaña a todo fundamento, el ocaso permanente de tantas promesas por amanecer. Las fronteras terminan aquí, en Palestina que no es, ni pretende ser, ni Roma ni Judea. Palestina es simplemente el nombre de la irreductible resistencia, de la imaginación de nuevas formas del vivir juntos, de la dislocación de toda geopolítica contemporánea. Palestina es la frontera última de la forma Estado, donde éste se revela en la extrema-dura de su violencia, en el desacato soberano de toda forma de derecho. Quizás, Palestina parece ser hoy, el rostro de todos los rostros, el resto desde el cual se interpela a nuestro presente, la tierra después de la última frontera, el lugar excluido de todo lugar, desde cuya catástrofe, se abren las puertas del paraíso. 